\title{
RETORIKA KOMUNIKASI POLITIK PKS LOVERS DI SOSIAL MEDIA DALAM PERSPEKTIF DRAMATISTTK KENNETH BURKE
}

\author{
Dini Safitri \\ Universitas Negeri Jakarta
}

\begin{abstract}
The purpose of this study provides an overview of political rhetoric PKS Lovers communication in social media post LHI arrested, as was charged with corruption in a bribery case kuoata meat imports, with PT Indoguna. Reputation PKS was known as the party of 'clean' anti-corruption, be gone. In Social Media, PKS was subjected to insults the haters. But the invective then got a reply from the lovers. The presence of the PKS Lovers enliven the world of social media. Various texts of political communication, production by PKS Lovers, including support of the lovers, but also became a target of the haters. The research method used a qualitative case study methodology. The results showed the rhetoric of political communication PKS Lovers showed PKS activity is sporadic activity, can't be managed well, and reactive. If there is an attack, they attack, but gave the impression of fanaticism, making target for haters.
\end{abstract}

Keywords: rhetoric, political communication, pks lovers

\section{PENDAHULUAN}

\section{Latar Belakang}

Pesta demokrasi, pemilu legislatif 2014, telah digelar pada Rabu, 9 April 2014. Komisi Pemilihan Umum (KPU) juga sudah menetapkan hasil rekapitulasi suara nasional pemilu legislatif 2014 pada Jumat (9/5/2014) tengah malam. Berikut hasil perolehan suara setiap partai:

1. Partai Nasdem $8.402 .812(6,72$ persen)

2. Partai Kebangkitan Bangsa (PKB) 11.298.957 (9,04 persen)

3. Partai Keadilan Sejahtera (PKS) $8.480 .204(6,79$ persen $)$

4. Partai Demokrasi Indonesia Perjuangan (PDIP) 23.681.471 (18,95 persen)
5. Partai Golkar 18.432.312 (14,75 persen)

6. Partai Gerindra $14.760 .371(11,81$ persen)

7. Partai Demokrat 12.728.913 (10,19 persen)"

8. Partai Amanat Nasional (PAN) 9.481 .621 (7,59 persen)

9. Partai Persatuan Pembangunan (PPP) 8.157.488 (6,53 persen)

10. Partai Hanura $6.579 .498(5,26$ persen)

14. Partai Bulan Bintang $1.825 .750(1,46$ persen)

15. Partai Keadilan dan Persatuan Indonesia 1.143.094 $(0,91$ persen $)$ 


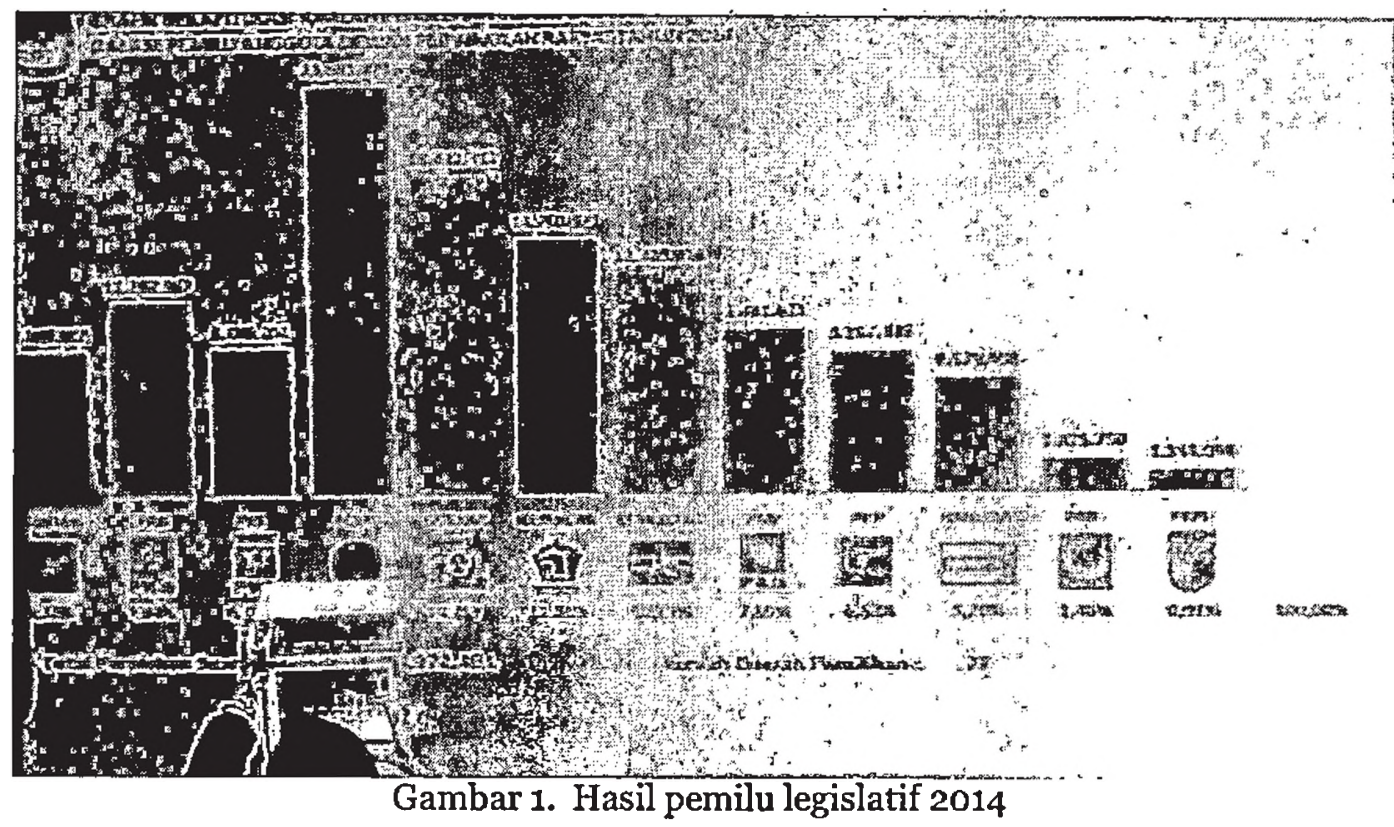

(Sumber: http://pontianak.tribunnews.com/2014/05/15/inilah-hasil-perolehan-suarapartai-politik-pemilu-2014)

Berdasarkan hasil diatas kita bisa mengetahui bahwa PKS berada diurutan nomor 7, dengan perolehan suara 6,79\%. Sebelum hasil tersebut dirilis, sejumlah lembaga survey juga telah merilis hasil hitung cepat. Salah satunya adalah IRC. IRC tidak hanya merilis perolehan suara, namun juga memprediksi perolehan kursi parpol di DPR, PKS diperkirakan memperoleh 34-45 kursi. ${ }^{1}$ Menanggapi hasil hitung cepat tersebut, Wasekjen PKS, Mahfudz Siddiq, mengatakan PKS bisa berbangga, walau suara tidak terlalu tinggi. Dan PKS juga bersyukur, karena bisa bertahan di tengah badai.

" Jadi menurut saya, ada sejumlah keberkahan dari peta hasil cepat pileg 2014. Pertama, PKS mampu bertahan di tengah kesulitan" ujar Wasekjen PKS, Mahfudz Siddiq"2

\section{Ibid}

2

http://nasional.inilah.com/read/detail/2090617/pkskami-bertahan-di-tengah-badaił.UOYuXaiSyYk
Pernyataan Mahfudz tersebut disebabkan, karena di awal 2013, tepatnya pada 31 januari 2013, mantan Presiden PKS, Luthfi Hasan Ishaaq (LHI), ditangkap KPK, karena diduga terlibat dalam suap, kasus daging impor, dengan PT Indoguna Utama. - Peristiwa penangkapan ini membuat reputasi PKS yang sebelumnya dikenal sebagai partai 'bersih' yang anti korupsi, menjadi lenyap. Selain itu, dalam perkembangannya, kasus ini semakin menjadi sorotan, karena banyak konstruksi framing lain yang ditampilkan media, salah satunya berita tentang rekan LHI, AF, yang banyak "terlibat" dengan sejumlah wanita cantik. Begitupun LHI, difakta persidangan terkuak, memiliki 3 istri. Dan istri yang ketiga masih berusia remaja dan berstatus pelajar SMK. Sehingga, dengan kasus LHI ini, image PKS menjadi sangat negatif, karena disandingkan dengan bunyi pepatah lama yang membuat seseorang jatuh adalah karena 3 hal, yaitu harta, tahta dan wanita. 
PKS pun banyak mendapat makian publik, bahkan di sosial media terbentuk istilah PKS Haters. PKS haters ini adalah warga sosial media yang selalu memberitakan atau memberikan komentar negatif tentang PKS. Menghadapi kondisi tersebut, PKS membuat sejumlah langkah penyelamatan partai, salah satunya dengan konsolidasi. internal. Dan usaha ini cukup membuahkan hasil di Pileg 2014, dimana perolehan suara PKS berdasarkan hasil hitung cepat, menunjukkan PKS mampu mempertahankan suara politiknya seperti di 2009.

PKS bersyukur bisa meraih suara seperti hasil hitung cepat ini. "Artinya suara PKS 2014, tunjukkan mampu mempertahankan suara politiknya di 2009. Alhamdulillah, target minimal tercapai" kata Mahfudz Siddiq ${ }^{3}$

\begin{tabular}{llr}
\multicolumn{2}{c}{ Walaupun demikian, PKS } \\
mengandaikan tim tabulasi data \\
perhitungan & sendiri, daripada
\end{tabular} mempercayai hasil hitung cepat yang ada. Menurut Mahfudz, hal ini dikarenakan PKS merasa masih ada pihak-pihak yang tidak senang dengan mereka.

"Godaan perbedaan pandangan dalam melihat hasil pileg akan ada. Jiga akan ada pihak lain yang akan "ganggu" PKS. Rapatkan terus shaf ini" tulis Mahfudz dalam akun twitter miliknya @MahfudzSiddiq. Kamis (10/4/2014)

${ }_{4}^{3}$ Ibid

http://nasional inilah.com/read/detail/2090628/pksmasih-ada-yang-ingin-ganggukami\#.UOYeFKiSvYk
Berdasarkan statment diatas, menarik untuk mencermati mengapa Mahfudz membuat pernyataan bahwa, PKS: Masih ada yang ingin ganggu kami? Hal ini tidak terlepas dari praha yang menimpa PKS, setahun sebelum pileg. Pasca ditangkapnya LHI dalam kasus dugaan korupsi kuota impor sapi, hampir semua lembaga survei meramalkan PKS akan terlempar dari panggung politik Indonesia, karena akan gagal melampaui ambang batas parlemen sebesaar 3,5\% yang mengakibatkan PKS akan gagal mengirimkan wakilnya ke parlemen. Bahkan, Lingkaran Survei Indonesia (ISI) pada survei terakhir sebelum pemilu legislatif, yang dirilis pada Minggu (2/2/2014), menyebutkan PKS merupakan satu dari empat partai yang tak akan ke Senayan. Peneliti LSI, Adjie Alfarab, saat merilis survei itu mengatakan, dengan rentang kesalahan 2,9 persen dan 30,1 persen dari 1.200 persen responden belum menentukan pilihan, nasib PKS tak akan tertolong. 5

Berikut sejumlah survei yang memprediksi PKS akan terlempar dari parlemen ${ }^{6}$ :

1. Survei Kompas: PKS 2,5 persen

2. Survei SMRC: PKS 2,7 persen

3. Survei LSJ: PKS 2,6 persen

4. Survei IRC: PKS 2,8 persen

5. Survei LSN: PKS partai Islam paling tidak disukai

Khusus untuk survei LSN ini, dalam rilis survei LSN, PKS menjadi partai Islam paling tidak disukai, karena sejalan dengan sentimen negatif yang diterima PKS lewat pemberitaan media.

5

http://nasional.kompas.com/read/2014/04/10/08285 60/Anis.Matta.Suara.PKS.Masih.Sesuai.Perkiraan

${ }^{6}$ http://m.merdeka.com/politik/5-survei-iniprediksi-pks-bakal-jeblok-di-2014.html 
Sepanjang Mei-Oktober 2013, sebanyak $33,23 \%$ pemberitaan di lima media cetak nasional, dan $21,48 \%$ di media online, memberitakan negatif, tentang PKS. Bakan, LSN mengklaim, loyalitas pendukung PKS, juga paling lemah dibanding empat partai Islam yang lain. Hanya $36,4 \%$ responden yang memilih PKS pada Pemilu 2009 akan memilih lagi partai yang sama pada 2014. Sementara itu, loyalitas pendukung tertinggi adalah PPP dengan 64,7 \%, kemudian PAN 54,2 $\%$, PKB 50,1 \%, dan PBB 40,1\%.7

Apa yang menjadi gambaran survei ISN diatas, pada kenyataannya tidak terbukti, khususnya untuk loyalitas pendukung PKS. Sebagaimana diketahui, PKS adalah satu-satunya partai kader yang memiliki basis yang solid. Ini terbukti dengan membludaknya kader dan simpatisan PKS saat kampanye akbar di GBK, pada ahad 16 maret 2014.

Atas prestasi tersebut, PKS mendapatkan piagam rekor Muri sebagai peserta kampanye terbanyak di GBK. ${ }^{8}$ Begitu pula hasil perolehan suara PKS dalam hitung cepat, dinilai sebagai "berkah" oleh ketua departemen politik CSIS, Philip J Vermonte.

Hasil PKS kali ini adalah berkah, karena terkait isu sebelumnya, PKS (diperkirakan) hanya mampu berada di angka 3 persenan" ucap Philip. Selain itu, lanjut Philip, perolehan suara PKS masih bisa dikatrol, karena partai pimpinan

Ibid

http://news.detik.com/read/2009/04/07/181308/111 1930/700/kampanve-diikuti-122-ribu-orang-pksmasuk-muri
Anis Matta ini memiliki kader yang loyal dan basis pemilih tetap. 9

Berdasarkañ deskripsi singkat diatas, penulis berkesimpulan, bahwa loyalitas kader PKS, merupakan bagian dari Rhetorika Komunikasi Politik PKS di sosial media. Rhetorika ini mencapai klimaksnya dalam Pileg 2014, Pasca Kasus LHI. Rhetoriks tersebut dikonstruksi melalui framing kader PKS yang dikenal begitu aktif di sosial media, sehingga muncul istilah "PKS Lovers". PKS Lovers adalah sebutan warga sosial media terhadap orang-orang yang memberitakan atau mengomentari PKS dari sisi positif dan cenderung memberi pembelaan terhadap hal negatif tentang PKS. Tidak dapat dipungkuri, kehadiran PKS Lovers inilah, yang membuat PKS tetap eksis di pileg 2014. Mereka hadir untuk membuat konstruksi framing tandingan yang melawan serangan PKS haters dan media mainstream yang cenderung membuat konstruksi framing negatif tentang PKS. Berikut ini salah satu yang desain PKS Lovers di sosial media pasca Pileg 2014 (Lihat Gambar 2):

Menurut Kenneth Burke, bahwa setiap bentuk-bentuk komunikasi adalah sebuah drama. Karenanya seorang pembicara hendaknya mampu 'mendramatisir' keadaan khalayaknya. Lebih lanjut Kenneth Burke mengatakan definisi dari retorika telah berkembang jauh sejak retorika naik sebagai bahan studi di universitas. Ada perbedaan antara retorika klasik dan praktek kontemporer dari retorika (teks tertulis dan visual). Politik yang bersifat transaksional dengan menggunakan lambang untuk

9

http://news.detik.com/pemilu2014/read/2014/04/09 1193530/2550491/1562/csis-hasil-verolehan-suaragerindra-dan-pks-di-pileg-merupakanberkah?9922022 
mengidentifikasi pembicara dengan pendengar melalui pidato, kegiatan bekerja sama dalam merumuskan nilai, persuasi dan yang dipersuasi saling kepercayaan dan pengharapan mereka.

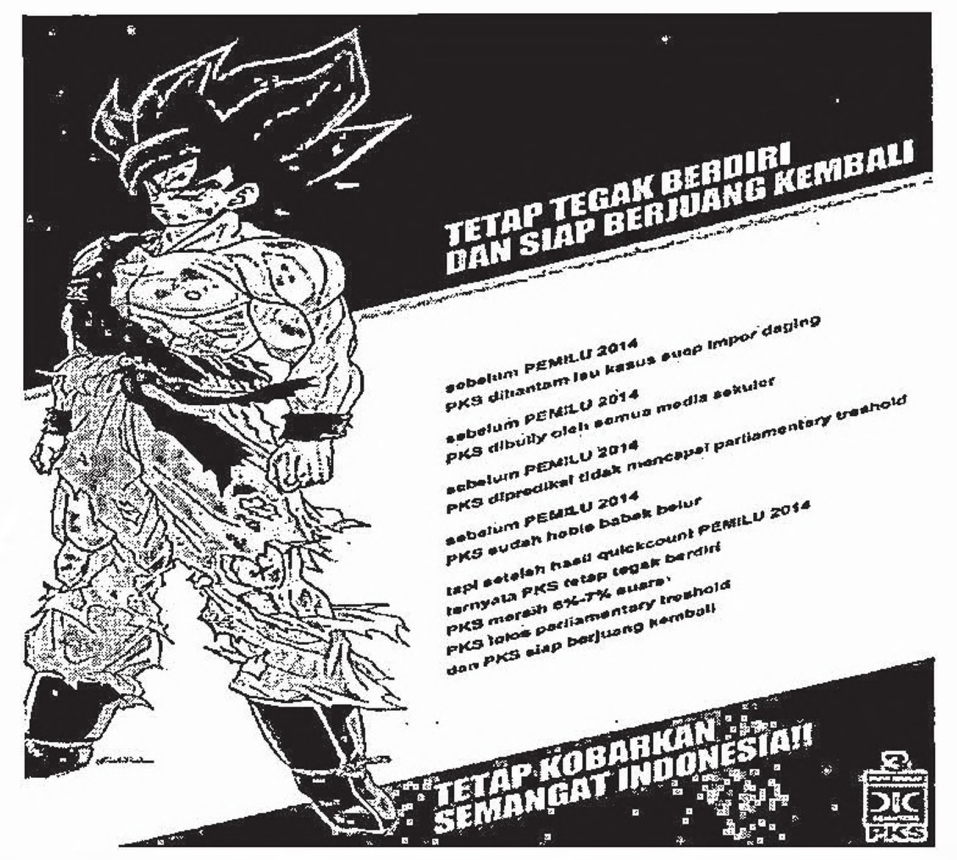

Gambar 2. Desain PKS Lovers di sosial media pasca Pileg 2014

Teori dramatisme adalah teori yang mencoba memahami tindakan kehidupan manusia sebagai drama. Dramatisme, sesuai dengan namanya, mengonseptualisasikan kehidupan sebagai sebuah drama, menempatkan suatu focus kritik pada adegan yang diperlihatkan oleh berbagai pemain. Seperti dalam drama, adegan dalam kehidupan adalah penting dalam menyingkap motivasi manusia. Dramatisme memberikan kepada kita sebuah metode yang sesuai untuk membahas tindakan komunikasi antara teks dan khalayak untuk teks, serta tindakan di dalam teks itu sendiri.

Dengan teori ini, penulis ingin mencoba memahami tindakan PKS Lovers dalam mengonseptualisasikan ide serta nilai ideologis perjungannya. Bagaimana PKS lovers menempatkan fokus kritik dalam nilai, kepercayaan dan pengharapan mereka terhadap politik. Apa saja yang memotivasi PKS Lovers dalam bertindak di sosial media, sehingga melahirkan tindakan di dalam teks di sosial media.

Mengacu pada Burke, drama adalah metafora yang berguna bagi ideide. Burke mengemukakan mengapa drama itu terjadi, karena tiga alasan, yaitu: (1) drama menghasilkan cakupan yang luas, dan Burke tidak membuat klaim yang terbatas; tujuannya adalah untuk berteori mengenai keseluruhan pengalaman manusia. Metafora dramatis khususnya berguna dalam menggambarkan hubungan manusia karena didasarkan pada interaksi atau dialog. (2) drama cenderung untuk mengikuti tipe-tipe atau genre yang mudah dikenali: komedi, musical, melodrama dan lainnya. Burke merasa bahwa cara kita membentuk dan menggunakan bahasa dapat berhubungan dengan cara drama manusia ini dimainkan. (3) drama selalu ditujukan 
pada khalayak. Drama dalam hal ini bersifat retoris. Burke memandang sastra sebagai "peralatan untuk hidup", artinya bahwa literature atau teks berbicara pada pengalaman hidup orang dan masalah serta memberikan reaksi untuk menghadapi pengalaman ini. Dengan demikian, kajian dramatisme mempelajari cara-cara dimana bahasa dan penggunaannya berhubungan dengan khalayak.

Gambaran yang dikemukakan Burke diatas juga tidak bertentangan seperti yang pernah diungkapkan Berger dan Luckman mengenai Konstruksi realitas. Dimana terdapat tiga istilah dalam mengambarkan konstruksi realitas, yaitu ekstermalisasi, obyektivasi, dan internalisasi. Ketiga istilah tersebut dipakai untuk menggambarkan hubungan dialektik antara individu dan masyarakat. Yang dimaksud dengan individu dalam penelitian ini adalah PKS Lovers, dan yang dimaksud dengan masyarakat adalah masyarakat sosial media.

Menurut Berger dan Luckman, Eksternalisasi menunjukan pada kegiatan kreatif manusia; Obyektivasi menunjuk pada proses dimana hasil dari aktivitas kreatif tadi, mengonfrontasi individu sebagai kenyataan obyektif, dan Internalisasi menunjuk pada proses 'dimana kenyataan eksternal itu menjadi bagian dari kesadaran subyektif individu. Dalam penelitian ini yang dimaksud dengan kegiatan kreatif manusia adalah aktivitas PKS Lovers di Facebook, dapat berupa foto yang diberi komentar, tulisan yang dibuat PKS Lovers, share dari link sosial media yang lain, share dari sesama PKS Lovers, dll.

Hasil dari aktivitas PKS Lovers di Facebook bisa dilihat dari komentar atau dialog yang terjadi antara pemilik akun dan teman pemilik akun, atau jumlah teman pemilik akun yang memberikan tanda jempol keatas atau kebawah. Tanda jempol keatas, bermakna teman pemilik akun setuju dengan apa yang ditampilkan PKS Lovers dalam halaman Facebooknya. Sedangkan tanda jempol kebawah, bermakna teman pemilik akun tidak setuju dengan apa yang ditampilkan PKS Lovers dalam halaman Facebooknya. Sedangkan kesadaran subyektif PKS Lovers bisa diihat dari apa yang ditampilkan PKS Lovers di halaman Facebooknya.

Dalam hal ini penulis mengambil kurun waktu setahun, yaitu dari 24 Juni 2013 sampai pilpres 9 Juli 2014. Alasan pemilihan tanggal 24 Juni 2013, dipilih menjadi awal waktu penelitian dikarenakan pada hari tersebut sidang perdana LHI digelar di Pengadilan. Sedangkan Pilpres 9 Juli 2014, dipilih karena intensitas posting PKS Lovers telah mencapai perpaduan antara klimaks dan anti klimaksnya dalam mengukuhkan eksistensi PKS di pangung politik Indonesia.

Selain konstruksi realitas, penelitian ini juga ingin mengambarkan analisis framing PKS Lovers terkait pemberitaan kasus LHI dan eksistensi PKS di Pileg 2014, yang kemudian berlanjut di Pilpres 2014. Tokoh yang dipakai adalah Robert $\mathrm{N}$ Entman. Menurut Entman, konsep framing digunakan untuk menggambarkan proses seleksi dan penonjolan aspek tertentu dari realitas oleh media. Framing memberi tekanan lebih pada bagaimana teks komunikasi ditampilkan dan bagian mana yang dianggap penting atau ditonjolkan oleh pembuat teks. Entman melihat framing dalam dua dimensi besar, yaitu seleksi isu dan penekanan atau penonjolan aspek-aspek tertentu dari realitas atau isu. Adapun perangkat framing yang gunakan adalah: 
Tabel 1. Perangkat Framing Robert N Entman

\begin{tabular}{|l|l|}
\hline $\begin{array}{l}\text { Define problems } \\
\text { (pendefinisain masalah) }\end{array}$ & $\begin{array}{l}\text { Bagaimana suatu peristiwa / isu dilihat? sebagai apa? Atau } \\
\text { sebagai masalah apa? }\end{array}$ \\
\hline $\begin{array}{l}\text { Diagnose causes } \\
\text { (memperkirakan masalah } \\
\text { atau sumber masalah) }\end{array}$ & $\begin{array}{l}\text { Sebagai penyebab dari suatu masalah, siapa atau aktor yang } \\
\text { dianggap sebagai penyebab mereka? }\end{array}$ \\
\hline $\begin{array}{l}\text { Make moral judgement } \\
\text { (membuat keputusan } \\
\text { moral) }\end{array}$ & $\begin{array}{l}\text { Nilai moral apa yang disajikan untuk menjelaskan masalah? } \\
\text { Nilai moral apa yang dipakai untuk melegitimasi atau } \\
\text { mendelegitimasi suatu tindakan? }\end{array}$ \\
\hline $\begin{array}{l}\text { Treatment recomendation } \\
\text { (menekankan penyelesaian) }\end{array}$ & $\begin{array}{l}\text { Penyelesaian apa yang ditawarkan untuk mengatasi masalah/ } \\
\text { isu ?jalan apa yang ditawarkan dan harus ditempuh untuk } \\
\text { mengatasi masalah }\end{array}$ \\
\hline
\end{tabular}

Dalam penelitian ini penulis ingin menggambarkan konstruksi framing komunikasi politik PKS dalam pileg 2014 pasca kasus LHI di sosial media, dengan beberapa langkah, seperti: pendefinisian masalah LHI dan dialektika pileg dan pilpres 2014 dari kontruksi PKS Lovers di facebook, siapa yang dijadikan sumber masalah oleh PKS Lovers, apa yang menjadi pokok posting PKS Lovers di sosial media, konstruksi moral yang disosialisasikan PKS Lovers di facebook, serta cara penyelesaian kasus LHI dan dukungan terhadap PKS versi PKS Lovers di Facebook.

Berdasarkan paparan diatas, penulis tertarik untuk mencari tahu bagaimana rhetorika komunikasi politik PKS lovers dalam pileg 2014 pasca kasus LHI di sosial media?

\section{METODE}

Jenis penelitian yang digunakan adalah penelitian kualitatif. Penelitian kualitatif bertujuan mempertahankan bentuk dan isi perilaku manusia dan menganalisis kualitas-kualitasnya, dan bukan mengubahnya menjadi entitasentitas kuantitatif. Penelitian kualitatif berasumsi bahwa penelitian sistematik harus dilakukan dalam suatu lingkungan yang alamiah dan langsung kepada tindakan atau interaksi manusianya itu sendiri dalam memaknai dan menginterpretasikan kejadian-kejadian sosial, dan bukannya kepada lingkungan yang artifisial seperti eksperimen.

Dengan pendekatan kualitatif, penulis berharap penelitian ini dapat memberikan pembahasan secara mendalam mengenai konstruksi realitas PKS Lovers di fitur wall Facebook terkait Studi terhadap rhetorika komunikasi politik PKS Lovers. Apakah kegitan tersebut, memberikan hasil positif kepada citra PKS atau malah sebaliknya, atau bahkan kegiatan PKS Lovers tersebut menemui benturan dengan ideologi PKS?

Metode dalam penelitian ini adalah Metode Aralisis dramatisme, framing dan Konstruksi Realitas Berger dan Luckman. Metode analisis Framing adalah salah satu metode analisis teks yang berada dalam kategori penelitian konstruksionis. Menurut Eriyanto (2002:37), paradigma konstruksionis memandang realitas kehidupan sosial bukanlah realitas yang natural, tapi hasil dari sebuah konstruksi. 
Peneliti tertarik untuk mengetahui bagaimana perspektif atau cara pandang yang digunakan oleh PKS Lover pada wall FB ketika menyeleksi isu dan menulisnya di wall FB. Dalam konteks inilah wacana PKS Lovers di wall FB kemudian menjadi arena perang simbolik antara pihak-pihak yang berkepentingan dengan suatu objek rhetorika. Perdebatan yang terjadi di dalamnya dilakukan dengan cara-cara yang simbolik, sehingga lazim ditemukan bermacam-macam perangkat linguistik atau perangkat rhetorika yang umumnya menyiratkan tendensi untuk melegitimasi diri sendiri dan mendelegitimasi pihak lawan.

Subjek penelitian adalah PKS Lovers yang aktif di sosial media. Subjek penelitian dipilih berdasarkan purposif sampling, informan ini juga telah merasakan fenomena dari permasalahan peneliti, serta bersedia untuk mengeksplorasi dan mengartikulasikan pengamalan mereka secarạ sadar.

Informan dalam penelitian ini dipilih peneliti dengan kriteria: 1) PKS Lovers yang aktif di sosial media, FB. 2) PKS Lovers yang selalu mengupdate FB tentang PKS selama dalam rentang waktu seminggu. 3) PKS Lovers yang memiliki banyak teman, komentar dan tanda suka. Berdasarkan kriteria tersebut, saya mendapatkan enam orang informan yang facebook nya menjadi objek penelitian dalam penelitian ini. Pada penelitian ini, peneliti menggunakan dua teknik pengumpulan data yaitu observasi partisipatif (participant observation), dan analisis dokumen.

\section{HASIL DAN PEMBAHASAN}

Rhetorika komunikasi politik PKS Lovers menggunakan teori dramatisme yang mencoba memahami tindakan kehidupan manusia sebagai drama. Dramatisme, menempatkan fokus kritik pada adegan yang diperlihatkan oleh berbagai pemain. Pada setiap adegan ada motivasi manusia di dalamnya. Tindakan komunikasi politik PKS Lovers terlihat dari teks PKS Lovers di Facebook. Bagaimana mereka bertindak di dalam teks itu sendiri ? Dari sumber mana PKS Lovers dapat mengonseptualisasikan ide serta nilai ideologis perjungannya. Bagaimana PKS lovers menempatkan fokus kritik dalam nilai, kepercayaan dan pengharapan mereka terhadap politik. Apa saja yang memotivasi PKS Lovers dalam bertindak di sosial media, sehingga melahirkan tindakan di dalam teks di sosial media.

PKS Lovers memiliki panggung drama yang besar, dan mendapat perhatian yang luas, setelah LHI resmi di tahan dalam kasus dugaan suap. Mulai dari Drama penahanan LHI, PKS Lovers kemudian mendapatkan pengalaman pahit manisnya berhetorika di sosial media. Mereka masuk dalam kehidupan net citizen yang didasarkan pada interaksi atau dialog. Drama yang dilakoni PKS Lovers pun cenderung untuk mengikuti tipe-tipe atau genre yang mudah dikenali, yaitu melodrama.

Drama dalam hal ini bersifat retoris. Teks Melodrama PKS Lovers, meminjam teori Burke, memandang teks di Facebook sebagai pengalaman hidup yang tidak menyenangkan, merupakan ujian, dan harus terus disikapi dengan sikap yang positif. Berikut ini salah satu teks PKS Lovers yang memberikan reaksi untuk menghadapi pengalaman ditangkapnya LHI: 
YS shared a link.

January 31

Banyak kader PKS yang saking semangatnya menaruh komentar macam-macam terkait proses hukum terhadap Ust LHI, tanpa pemahaman yang cukup terhadap proses hukum itu sendiri, sehingga tidak sedikit komentar-2 nya keliru dan nyasar-nyasar tidak karuan.

Padahal sikap yang terbaik adalah yang dianjurkan oleh Ust LHI sendiri, yaitu tetap tenang, dan menahan diri, termasuk menahan diri dari komentar-komentar yang salah kaprah, dan juga seperti yang sikap yang dicontohkan oleh Ust Tifatul Sembiring dan sejumlah qiyadah Partai lainnya yang menyerahkan semuanya pada proses hukum positif di NKRI, yang paling penting di masa-masa berat ini tetap mejaga hubungan baik dengan Allah SWT, memohon petunjuk agar dibukakan yang mana yang benar dan yang mana yang salah, dan tidak mengurangi semangat dalam melakukan kebaikan, serta tidak malu untuk tetap menghidupkan wacana anti-korupsi dalam setiap liqoat-liqgoat kita, apapun yang terjadi.

http://www.bersamadakwah.com/2013/01/kulwit-tifatul-sembiring-terkait-status.html

Kulwit Tifatul Sembiring terkait Status Tersanqka LHI L_Bersama Dakwah

www.bersamadakwah.com

Bersama Dakwah: Kulwit Tifatul Sembiring terkait Status Tersanaka LHI - Media dakwah yang menyajikan berita dunia Islam, artikel Islami, tafsir Al-Ouran, hadits, khutbah Jumat, fiaih. materi tarbivah dan download aratis

1715Like · - Share Didin Kristinawati, Rokhman Fauzi, Abdul Wahid Abdullah and 14 others like this.

Teks diatas adalah teks yang direproduksi kembali oleh PKS Lovers, ia hanya meneruskan bagaimana arahan dan pimpinan (qiyadah) partai, agar PKS Lovers tetap tenang dan menjaga hubungan baik dengan Allah, dan tetap berbuat baik dengan cara tetap menghidupkan wacana anti korupsi. Intinya adalah, apapun yang terjadi dengan LHI, biarlah diproses secara hukum dan yang lainnya tetap bertindak seperti sebelumnya, berbuat baik

Dari teks tersebut, terlihat bagaimana kepercayaan PKS Lovers terhadap pemimpin partai. Hal ini terjadi karena ada hubungan dialektik antara individu dengan ideologi partai. Mengacu pada Berger dan Luckman, hubungan dialektik ini terjadi melalui tiga momen stimultan, yaitu eksternalisasi, obyektivasi dan internalisasi. Eksternalisasi menunjukan pada kegiatan kreatif manusia; dalam hal ini PKS Lovers memposting tentang PKS adalah bagian dari kreatifitas dalam instruksi partai. Mereka mengemasnya dengan bahasa sendiri, namun tetap dalam koridor seruan qiyadah (pemimpin) partai.

Obyektivasi menunjuk pada proses dimana hasil dari aktivitas kreatif tadi, dimana PKS Lovers mengonfrontasi seruan qiyadah sebagai kegiatan yang harus disebarluaskan melalui jejaring sosial, disamping liqoat-liqoat (forum pengajian) PKS Lovers. Internalisasi menunjuk pada proses dimana aktivitas bergiat di sosial media adalah aktivitas harian yang menjadi pengalaman sehari-hari PKS lovers. Aktivitas ini akan bernilai ibadah bila ditujukan kepada hal-hal yang positif. Seperti yang tersurat di contoh teks PKS Lovers diatas.

Selain konstruksi realitas, penelitian ini juga menganalisis framing PKS Lovers terkait pemberitaan kasus LHI dan eksistensi PKS di Pileg 2014, yang kemudian berlanjut di Pilpres 2014. Berdasarkan metode framing Entman, PKS Lovers melakukan proses seleksi dan penonjolan aspek tertentu dari PKS. Mereka melihat kasus LHI sebagai 
cobaan. Penyebabnya adalah ketidaksenangan sejumlah golongan terhadap kiprah PKS di panggung politik Indonesia. Nilai moralnya adalah, bagi PKS Lovers, apapun yang terjadi pada LHI, PKS tetap solid, dan dapat melewati cobaan ini. Penyelesaianya untuk kasus LHI diserahkan ke ranah hukum, untuk kader tetap seperti sebelumnya, berbuat baik.

Sementara itu, selain contoh teks diatas, masih banyak teks yang menonjolkan bahwa Kasus LHI merupakan sebuah konspirasi. Penyebabnya ada pihak-pihak yang tidak menyukai PKS, mereka diduga datang dari pemerintah yang berkuasa yang tidak suka PKS menjadi pemenang pemilu 2014, dan didukung oleh bantuan zionis (AS) yang memiliki kepentingan internasional agar Islam tidak menjadi 'solusi' untuk seluruh alam (Islam versus yahudi). Mereka heragumen bahwa LHI sudah lama menjadi target operasi dengan skenario untuk membubarkan PKS. Disatu pihak, konspirasi ini berusaha membuat PKS dan
KPK seolah dibenturkan, sehingga PKS dibenci oleh masyarakat. Hal ini dilakukan, karena diantara sejumlah lembaga yang ada, KPK dinilai sebagai lembaga yang masih bisa diharapkan memberi keadilan bagi rakyat.

\section{Pihak yang berkonspirasi} melakukan penggiringan opini, PKS tidak menyukai KPK karena tebang pilih. Pihak konspirasi juga menguasai framing Media mainstream. Pihak konspirasi meframing Kasus LHI dengan cara tidak menyentuh proses kasus korupsi, tapi lebih kepada melodrama yang menonjolkan pembunuhan karakter LHI sebagai tokoh antagonis yang mencintai harta, tahta dan wanita. Nilai moralnya, PKS Lovers harus terus membendung konspirasi negatif ini dengan postingan yang menganulir framing media mainstream dan meramaikan dengan argumen yang menguatkan adanya konspirasi. Penyelesaiannya PKS Lovers akan terus ada untuk menyuarakan keadilan. Berikut contoh postingannya:

AT

February 3

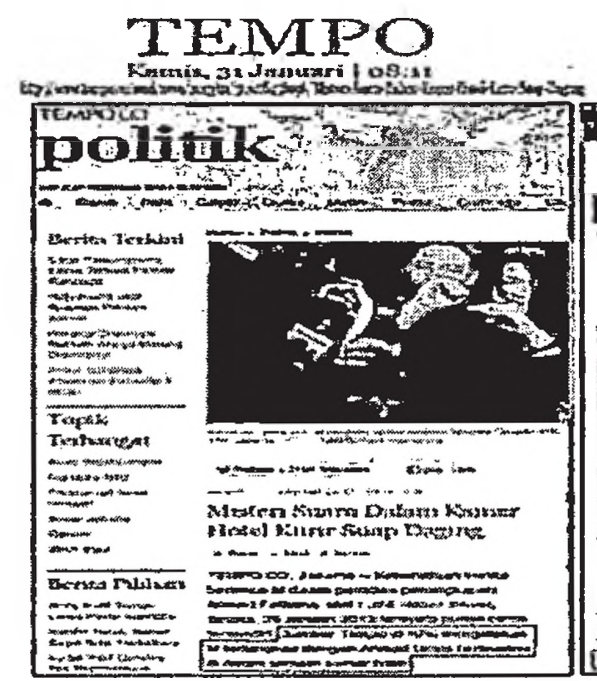

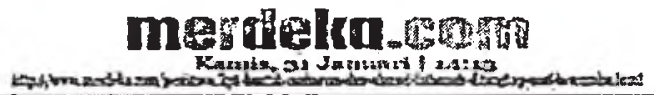

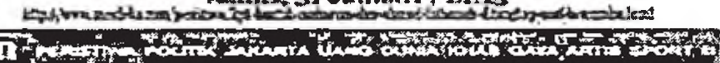

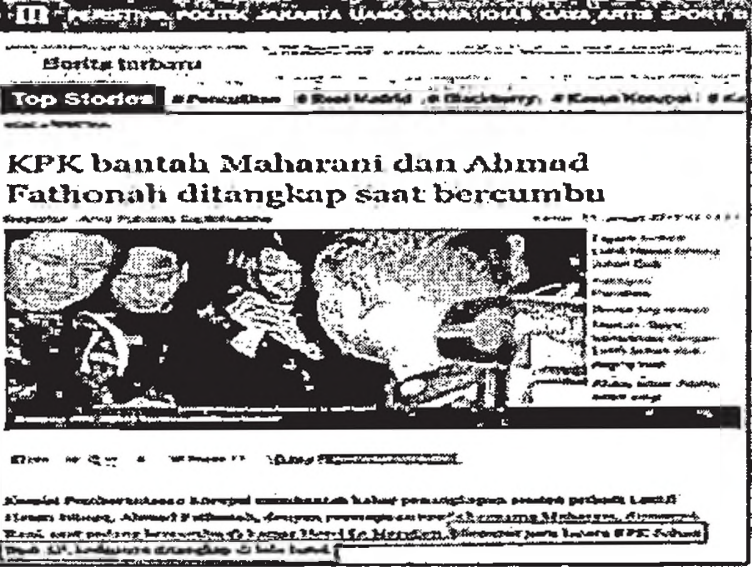


Dini Safitri, Retorika Komunikasi Politik PKS lovers di Sosial Media dalam Perspektif Dramatistik Kenneth Burke

\section{J P P}

May 13

Breaking News

ternyata Jubir KPK sudah diganti.

Ga tanggung-tanggung, diganti fungsionaris PKS

- sumber MetroTV nan terpercaya

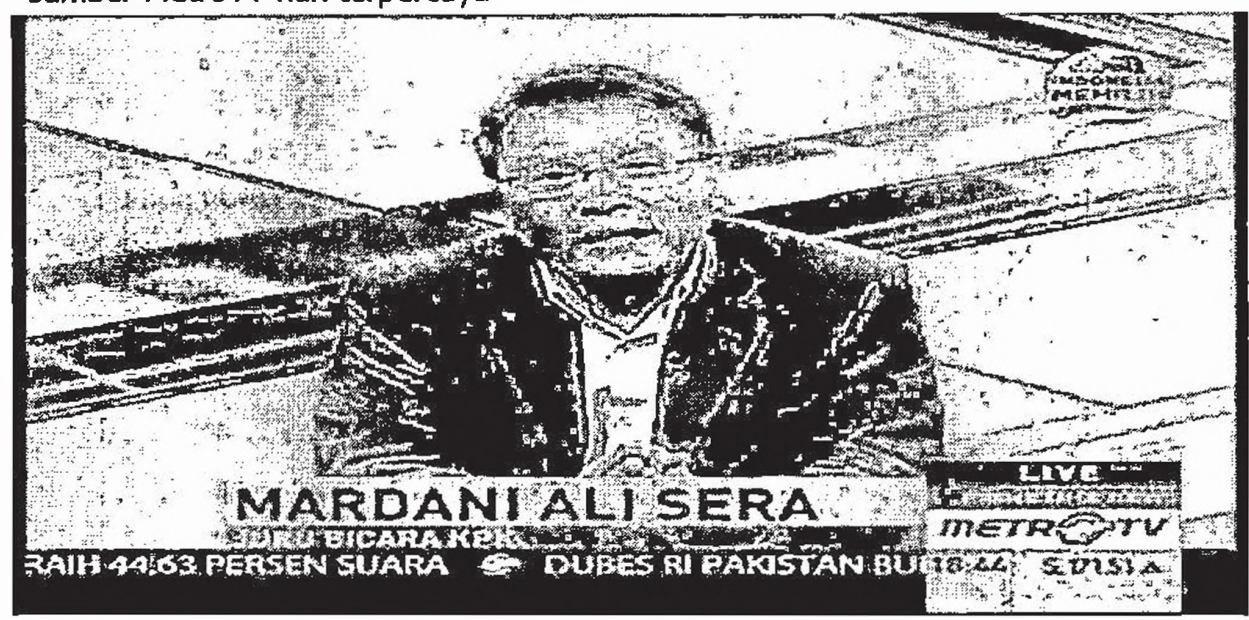

\section{A T I}

May 12

gara2 video Fahri Hamzah, KPK takut dengan Demokrat soal pembubaran partai karena TPPU http://youtu.be/IwA086k40gU — with Yugi Sukriana and 47 others.

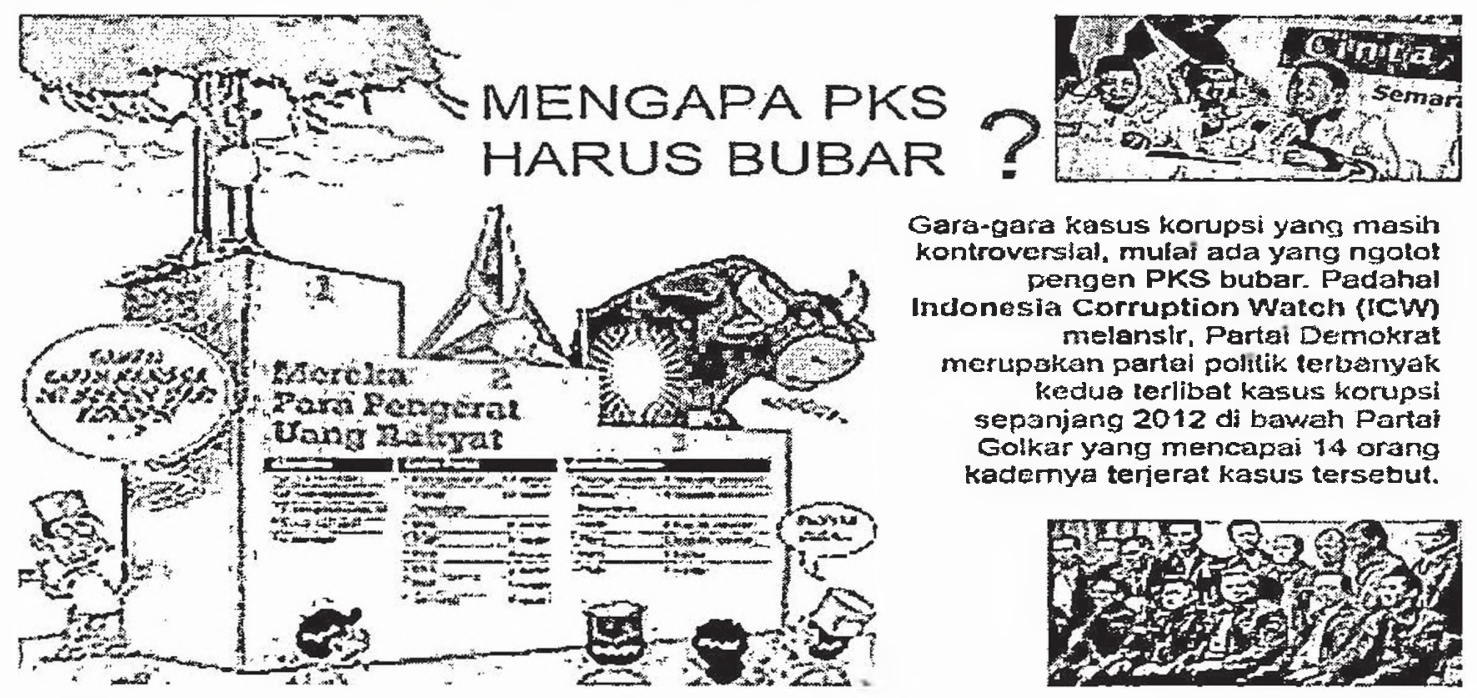

6979129Like - Share Pamungkas Taufiq Saputro and 68 others like this. 
Tiga dari postingan dari tiga PKS Lovers diatas, disatu sisi menguatkan internal dari PKS Lovers, namun disisi lain juga membangkitkan munculnya istilah PKS haters. PKS haters menilai bahwa PKS Lovers ini terlalu berlebihan, mereka selalu mengkritisi tindakan dari PKS Lovers. Selain memposting yang berseberangan dengan PKS Lovers, mereka biasanya juga masuk dalam komentar PKS Lovers.

Berbeda dari PKS Lovers yang kerap memberikan komentar dengan protes dalam bahasa sindiran, PKS Haters kerap tampil dengan makian. Fenomena ini menjadikan perilaku bulying kerap terjadi dalam interaksi PKS Lovers bersama net citizen. PKS Lovers lebih berperan untuk menahan serangan haters, semakin terus diserang, mereka semakin aktif. PKS Lovers juga sering meneruskan pesan yang berisikan pembelaan terhadap PKS. Terkadang pesan ini adalah pesan hoaks, dan mayoritas PKS Lovers kerap terjebak dalam pesan hoaks ini. Fenomena ini menjadi blunder untuk PKS Lovers. Terlebih lagi, media jejaring sosial yang kerap menjadi rujukan PKS juga melakukan hal serupa. Hal ini menimbulkan kesan bahwa tindakan PKS Lovers ini belum dikontrol dengan baik, masih tindakan sporadis yang belum dikelola dengan profesional dan sifatnya reaktif. Bila diserang, balas menyerang, namun menimbulkan kesan fanatisme berlebihan yang menjadi sasaran tembak para PKS Haters.

\section{PENUTUP}

Retorika komunikasi politik PKS Lovers, bila ditinjau dari dramtisme burke, konstruksi berger dan framing entman, dapat dapat menjelaskan motivasi dalam tindakan simbolik PKS Lovers. Bagaimana aktor bertindak, adegan yang disusun untuk mencapai tujuan, dengan sikap kausalitas yang menyebabkan PKS Lovers bergerak lebih karena ada aksi penyerangan dari kelompok haters. Sebagai cara pertahanan diri, yang terkadang menjadi blunder. Namun ini menjadi pengalaman berharga bagi para Lovers yang belum lama berkecimpung sebagai pasukan tempur PKS di sosial media, maupun dalam bidang komunikasi politik. Belajar tujuan misteri yang biasa berbalut linguistik aktor komunikasi politik. PKS Lovers masih dalam tindakan sporadis, yang belum terorganisasi dengan baik. 


\section{DAFTAR PUSTAKA}

\section{BUKU}

Brissett, Dennis and Charles Edgley. Life As Theater:A Dramaturgical. USA: Transaction Publishers. 2005

Erivanto. Analisis Framing: Konstruksi, Ideologi, dan Politik Media. Yogyakarta: LkiS. .

2008

Griffin Emory A. A First Look at Communication Theory. Singapore: McGraw-Hill. 2003

Littlejohn, Stephen W. Theories of Human Communication. Belmont, California: Thomson Wadsworth Publishing Company. 2005

Muhtadi, Burhanuddin. Dilema PKS Suara dan Syariah. Jakarta: PT. Gramedia. 2012

Panuiu, Redi. Framing Analysis. Surabaya: Universitas dr.Sutomo. 2003

Pawito. Komunikasi Politik Media Massa dan Kampanye Pemilihan. Jakarta: Jalasutra. 2008

Rohim, Syaiful. Teori Komunikasi:Perspektif, Ragam,dan Aplikasi. Jakarta: Rineka Cipta. . 2009

Sobur, Alex. Analisis Teks Media, Suatu Pengantar Untuk Analisis Wacana, Analisis Semiotik, dan Analisis Framing. Bandung: Remaja Rosdakarya. 2001

\section{Online}

Kenneth Burke College Composition and Communication. Vol. 29, No. 4 (Dec., 1978), pp. 330-335. National Council of Teachers of English. Article Stable URL:http://www.jstor.org/stable/3 57013 (diakses 7 April 2014) http://www.socialbakers.com/facebookstatistics/(diakses 21 Mei 2013)

http://news.detik.com/read/2011/02/28/ 115915/1581022/10/pks-siapkan-500ribu-kader-kuasai-twitter-facebookdi-indonesia?ndg92203605 (diakese 21 Mei 2013)

http://pksmadiun.blogspot.com/2012/02 /kader-pks-waijib-Dunva-akunfacebook-dan.html (diakses $21 \mathrm{Mei}$ 2013)

http://wartakota.tribunnews.com/mobile /detil/berita/134011/media-sosialsenjata-ampuh-pks-menangi-pemilu (diakes 21 Mei 2013)

http://www.jpnn.com/read/2013/06/24/ 178368/Luthfi-Hasan-Ishaag-JalaniSidang-Perdana- (diakses 24 Juni 2013)

htto://beritapks.com/hanva-karenarencana-dapat-suap-presiden-pksiadi-tersangka/ (diakses 24 juni 2013)

http://news.detik.com/read/2013/06/02/ $164609 / 2262561 / 10 /$ anis-kasus-lhitak-pengaruhi-elektabilitas-pksmalah-makin-naik (diakses 25 Juni 2013)

http://oolitik.kompasiana.com/2013/o2/ oq/badai-politik-dan-masa-depanpks-532210.html (diakses 25 Juni 2013)

http://politik.kompasiana.com/2013/02/ 01/kasus-lhi-dan-upava-bullyterhadap-pks-520780.html (diakses 25 Juni 2013)

http://media.kompasiana.com/newmedia/2013/02/07/pertarunganpolitik-di-media-sosial-pkspemenangnva-521661.html (diakses 25 Juni 2013) 
htto://www.kaskus.co.id/thread/519e1197 552acfb301000001/woww--cyberwar-army-pks-cukup-tangguhlakukan-counter-attack-ke-kpk (diakses 25 Juni 2013)

http://www.rmol.co/read/2013/12/10/13 6074/Vonis-LHI-Tidak-Adil- (diakses 13 Maret 2013)

http://www.merdeka.com/politik/mantan -presiden-iadi-terdakwa-koruosi-pksklaim-tetap-bersih.html (diakses 13 Maret 2013) http://politik.news.viva.co.id/news/read/ 477777-ieblok-di-survei--pks-mantaptarget-15--suara-pemilu-2014 (diakses 13 Maret 2013)

http://m.kompasiana.com/post/read/633 676/2/iadi-haters-lovers-ataudoers.html (diakses 13 Maret 2013)

http://politik.news.viva.co.id/news/read/ 478019-lsi--tugas-berat-pks-iustruvakinkan-186-juta-pemilih--bukankader (diakses 13 Maret 2013) 